\title{
Benefit, cost and risk analysis on extending the forest roads network: A case study in Crasna Valley (Romania)
}

\author{
M. Drăgoi, C. Palaghianu, M. Miron-Onciul
}

Drăgoi M., Palaghianu C., Miron-Onciul M., 2015. Benefit, cost and risk analysis on extending the forest roads network: A case study in Crasna Valley (Romania). Ann. For. Res. 58(2): 333-345.

Abstract. The paper presents how the Analytic Hierarchy Process can be used to select the most suitable combination of new forest roads to build onto a forested area provided that social or ecological aspects are not jeopardized. All important features worth being considered when a new network of forest roads is designed were grouped in three types of criteria, which are benefits, costs and risks. Further, in order to ease the pairwise comparisons between criteria, both benefits and costs have been divided into private and social, while the risks refer to the events that might be triggered or favoured by the construction of new roads, like habitat fragmentation, landslides in case of heavy rainfall during the construction phase or even illegal cuttings. The outcome consists of a series of benefit-cost-and-risk indices and benefit-cost ratios, one for each combination of forest roads, including the status quo. The method has been tested on three combinations of new forest roads already designed for a small forest management unit located in Prahova County, encompassing 838.0 ha of mountainous forest. Keywords Stepwise Analytic Hierarchy Process, risk assessment, cost-benefit analysis, forest roads.

Authors. Marian Drăgoi (dragoi@usv.ro), Ciprian Palaghianu, Marius MironOnciul - University "Ştefan cel Mare” Suceava, Faculty of Forestry, Universităţii 13, 720229 Suceava, Romania.

Manuscript received July 31, 2014; revised March 30, 2015; accepted April 06, 2015; online first April 22, 2015.

\section{Introduction}

Many decisions related to environmental issues bring about conflicts between diverse stakeholders, simply because people have different interests and/or different views about the risks pertaining to environment. The incommensurability of people's values is the main reason for debating the appropriate structure of the decision making process (Martinez-Alier et al. 1998, Tadajewski 2009). In spite of their theoretical limitations, multi-criteria decision 
or evaluation methods have been employed for many years in order to select the most suitable way of dealing with or altering different environmental features. Several thorough analyses applying multi-criteria methods in natural resource management can be found in literature (e.g., Ananda \& Herath 2003a, Mendoza \& Martins 2006, Ananda \& Herath 2008, 2009).

Forests roads are quite controversial investments because they may trigger or increase soil erosion (Arnáez, Larrea et al. 2004, Correa, Roloff et al. 2007), habitat fragmentation, (Colchero, Conde et al. 2011) or even illegal logging (Ali, Benjaminsen et al. 2005). Hence the planning processes can become quite complex (Demir 2007), because all these negative side-effects may grow with the density of the forest road network.

The balance between environmental concern, economic effectiveness and social issues is fragile and controversial, because any new forest road affects more or less stakeholders, with different perceptions about the risks involved, especially in the endorsement phase of the project, when an environmental impact study is compulsory, according to Romanian regulations (Anonymous 2003). On the base of the environmental impact study, the environmental protection agency issues the environmental compliance, which is compulsory for kicking off the construction phase.

If the forest management is certified under FSC standards (which holds for our case study), public consultations with local communities and NGOs are also required by the certification procedure (Rametsteiner \& Simula 2003). So far, there is no methodological framework for these phases and this paper gives some hints for easing the analysis behind the whole decision making process and multi-criteria evaluation seems to be a promising solution for drafting the environmental impact study, where more alternatives can be contemplated.

The Analytic Hierarchy Process (AHP) helps evaluate each objective against an overall goal, and each decision that might be undertaken against each objective, using pairwise comparisons; mathematically, the weights of criteria against goal or alternatives against each criterion are given by the eigenvector of the comparison matrix, corresponding to the highest eigenvalue (Saaty 1980, 1994, 2013). Due to its flexibility in dealing with hierarchicallystructured problems, the method was mainly used to find out appropriate managerial options in forest planning (Kangas \& Kuusipalo 1993, Kurttila et al. 2000, Vacik \& Lexer 2001, Ananda \& Herath 2003b, Wolfslehner et al. 2005) or, more recently, to appraise the forest economic value (Šegotić \& Posavec 2007).

In matters concerning new forest roads AHP was applied to emphasise in a better way the benefits produced by forest roads in Japan (Masami 1995), while Coulter et al (2006) used it to prioritize new investments. As the assessment procedure of any new forest road is a problem per se, AHP was also used to draft the evaluation form for forest roads, using experts' opinions (Gumus 2009), to identify the adequate layers needed to design a forest road network through GIS (Rafatnia et al. 2006) or for analysing all types of roads within a certain area (Lugo \& Gucinski 2000).

In a recent study Hayati et al. (2013) have changed the conventional approach in the sense that each criterion was mapped on the forest area assigning to each pixel a fuzzy membership function (suitability index), ranging from 0 to 255 . Having a separate raster map for each forest road network it was possible to assess the degree to which each alternative meets each criterion by simply adding the suitability indices found along the forest roads included in each alternative. Finally the alternatives were pairwise assessed against each criterion using the average suitability index per kilometre of forest road, for each criterion.

Nowadays the Romanian forests are made accessible by $32,500 \mathrm{~km}$ of forest roads, 7,600 $\mathrm{km}$ of public roads that can be used for harvesting operations, and 1,450 $\mathrm{km}$ of roads owned by other industries, such as mining and oil 
extraction (Saphores et al. 2006, Anonymous 2007). This network provides access to only $65 \%$ of the Romanian forests; its density, averaged at $6.1 \mathrm{~m} / \mathrm{ha}$, is much less than the density reached in other European countries with comparable natural conditions.

However some investors, like Schweighofer Holzindustrie and Tornator, took advantage of the real estate market and bought quite large forestlands where their profit-oriented approach on forest management should fit into the multi-functionality principle which governs the Romanian forest policy, according to the latest Forest Act (Anonymous 2008). In order to reduce the cost of harvesting operations on a longer term, Cascade Empire SRL forest district (further referred to as OSCE), who is managing the Crasna forest, which is the study area briefly described in the next section, came up with the idea of developing new roads crossing the slopes in order to harvest the timber uphill and downhill with small cable cranes. This new opportunity shall be carefully analysed not only from an economic point of view but also from a social and ecological perspective.

This study shows how a well-known method for complex decision making processes can be used for selecting an appropriate combination of forest roads to construct in a forest estate, taking into account benefits, costs and risks $(B C R)$, raised by each investment alternative. The outcome of making such analyses is a series of $B C R$ indices, one for each alternative, and the highest $B C R$ index pinpoints the most appropriate alternative.

\section{Material and methods}

\section{Study area}

The study area is a forest district located along the Crasna Valley $\left(45^{\circ} 20^{\prime} 40.72^{\prime}\right.$ N, 2551'7.72”'E), Prahova County, with slopes ranging between 1110 and $1300 \mathrm{~m}$ above the sea level, typical for a mountainous region. The forest encompasses 838.0 ha and the main species are beech (Fagus sylvatica L.), Norway spruce (Picea abies (L) Karst.) and white fir (Abies alba Mill.). Foothills are very steep, while the middle and the upper slopes are moderate. Due to these natural conditions the existing main forest road, along Crasna Valley, is almost useless because the adjacent stands are not accessible to main yield harvesting operations due to the steep terrain.

Now OSCE is committed to apply low impact harvesting technologies based on mobile tower yarders, requiring a set of completely new forest roads, crossing the convex slopes in order to make accessible either uphill and downhill areas, like the ones presented in Figure 1. Outcrops are quite frequent and the main ecosystem service envisaged by the forest management plan is soil protection: in many situations there is no maturity age for the trees, meaning that trees are to be harvested only to make room for the new canopy in continuous cover, provided that the harvesting operations do not harm the remnant trees or the topsoil. Moreover, because the forest is located in a remote area where the local people of Crasna still have property rights over pastureland and forests ${ }^{1}$, and OSCE has applied for FSC certification for 314.5 ha, the social issues should be also taken into account.

Opportunity studies have been carried out for 11 new forest roads clustered in three alternatives, further compared with the current situation (status quo), which is a main forest road stretched along the Crasna Valley and two short connectors on the right hand. The map showing the planned forest roads is presented in figure 1 (Supporting Information), and the main aggregated outcomes of each alternative are summarized in Table 1.

\footnotetext{
1 OSCE has not certified the whole forest possession because the difference to 838.00 hectares was not yet purchased when the certification procedures had been initiated.
} 
Table 1 Forest areas assigned to different forest operations in Crasna management unit

\begin{tabular}{lc}
\hline Forest operations planned for the next two decades & Area (hectares) \\
\hline Green tree retention (Trees are harvested to the extent to which natural regeneration has & 86.7 \\
emerged and needs more light) & 400.0 \\
Commercial thinnings & 281.7 \\
Main yield cuttings & \\
\hline
\end{tabular}

\section{Method}

This study addresses a practical question which is common when a new network has to be designed: which is the most suitable combination of roads, given a set of criteria and a set of expected consequences the new roads might have. Typically this problem can be addressed by any multicriteria decision method (MCDM) but we have approached it as an Analytic Hierarchy Process (AHP), for this method allows handling more criteria structured at different levels (Figure 2). Such a structure is recommended due to numerous criteria taken into consideration when new forest roads are to be selected from a finite set of alternatives.

The difficulties in designing new forest roads are to be sought in the multi-dimensional nature of the problem: ecological, economic, technical and social aspects should be considered simultaneously and, as shown in a seminal study published more than 50 years ago by Miller (1957) an average person has the capacity to keep in mind only seven objects at the most (plus or minus two), without getting confused. Given that a decision maker has to operate with more criteria and construction alternatives, the risk of being overwhelmed is obvious.

When more than seven items are pairwise compared a consistent evaluation is difficult to attain and a hierarchy of criteria and sub criteria, as shown in Figure 2, allows the analysis of each level separately. The arrows presented in this diagram are usually top-down oriented, which makes sense just for breaking down the decision process, but not for the evaluation process, which is bottom-up oriented.
The evaluation problem decomposed into three separate sub-problems: one for benefits, one for costs, and one for risks, following the procedure proposed by Saaty and Vargas (2006), which ends up with a $B C R$ index, given by relation (1):

$B C R=\frac{\text { Benefit }}{\text { Cost } \cdot \text { Risk }}$

where all variables in the right term take values between 0 and 1 .

The benefits, costs and risks considered are summarized in Table 2. We preferred to break down the benefits and costs into private and social/environmental in order to ease the evaluation process: instead of making pair-wise comparisons on six types of benefits and eight types of costs, we have split the benefits and expenses in the two categories, considering equal weights for both.

Benefits, costs and risks were appraised using the same procedure, firstly based on pairwise comparisons of sub-criteria against each criterion, resulting an array of weights, shown in the second column of Table 6. Afterwards each alternative was compared with the status quo situation (A0), against each sub-criterion, given the following scores (Saaty 2013): 1 - equally important, 3 - a little bit more important; 5 - more important; 7 - much more important; 9 - very important.

One may notice that 1, 3, 5 and 7 correspond to three comparative forms (one for equality and three of superiority) and 9 to superlative form, which may be used in those situations when one criterion is very or extremely important. Given $a_{i j}$ which is the relative importance of criterion $i$ over criterion $j,(i, j=1, \ldots, n)$, the 


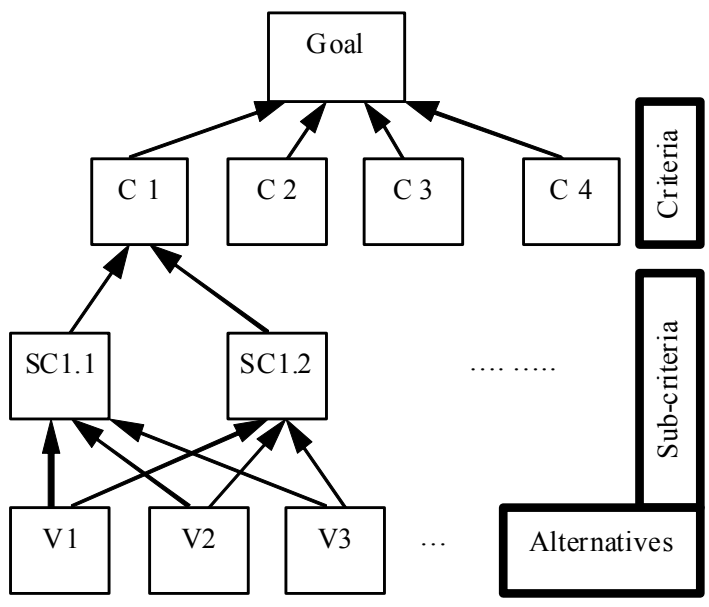

Figure 2 AHP principle

Table 2 Decision alternatives and their expected aggregate indicators

\begin{tabular}{|c|c|c|c|c|c|}
\hline Road & Length $(\mathrm{km})$ & \multicolumn{4}{|l|}{ Alternatives } \\
\hline $\begin{array}{l}\text { R.I } \\
\end{array}$ & 3.12 & $\mathrm{~A} 1$ & A2 & A3 & A0 \\
\hline R.I.1 & 0.54 & \multicolumn{4}{|c|}{ Combination of roads } \\
\hline R.II & 1.19 & \multirow{4}{*}{$\mathrm{I}+\mathrm{III}+\mathrm{IV}+\mathrm{V}+\mathrm{VI}$} & \multirow{4}{*}{$\begin{array}{l}\mathrm{I}+\mathrm{II}+\mathrm{III}+\mathrm{IV}+\mathrm{IV} .1 \\
+\mathrm{V}+\mathrm{VI}\end{array}$} & \multirow{4}{*}{ Whole network } & \multirow{4}{*}{ Current situation } \\
\hline R.III & 0.99 & & & & \\
\hline R.III.1 & 1.34 & & & & \\
\hline R.IV & 1.00 & & & & \\
\hline R.IV.1 & 3.15 & \multicolumn{2}{|c|}{ Road density (m/ha) } & & \\
\hline R.V & 4.27 & 12 & 170 & 260 & 24 \\
\hline R.VI & 2.29 & 13.1 & 17.9 & 26.9 & 2.4 \\
\hline R.VII & 1.81 & \multicolumn{4}{|c|}{ Average hauling distance (m) } \\
\hline R.VIII & 4.28 & \multirow{2}{*}{750} & \multirow{2}{*}{440} & \multirow{2}{*}{210} & \multirow{2}{*}{ more than $2000 \mathrm{~m}$} \\
\hline Total & 23.98 & & & & \\
\hline
\end{tabular}

complement $a_{j i}$ is automatically entered into the transposed position, meaning that $a_{i j}=1 /$ $a_{i j}$, and $a_{i i}=1$ where $n$ is the number of criteria compared. According to the mathematical procedure embodied into the AHP method, all these scores are recorded in a square matrix, as shown in equation (2):

$$
\begin{aligned}
A & =\left[\begin{array}{llll}
a_{11} & a_{12} & \cdots & a_{1 n} \\
\vdots & \vdots & \vdots
\end{array}\right] \\
A & =\left[\begin{array}{llll}
\tilde{a}_{11} & \tilde{a}_{12} & \cdots & \tilde{a}_{1 n} \\
\vdots & \ddots & \vdots \\
a_{n 1} & a_{n 2} & \cdots & a_{n n}
\end{array}\right]
\end{aligned}
$$

Then the weights associated to the $n$ criteria are given by the first eigenvector of $\mathrm{A}$, noted with $W^{T}$, which corresponds to the principal eigenvalue of $\mathrm{A}$, symbolized by $\lambda_{\text {max }}$ as shown in condition (3), which actually holds for any square matrix.

$$
A \cdot W=\lambda_{\max } \cdot W
$$

The eigenvector corresponding to the principal eigenvalue was estimated using the simplified procedure proposed by Winston (1994): (i) normalize matrix A by dividing each $a_{i, j}$ by the sum on column; doing so a new matrix 
$\mathrm{A}_{\text {norm }}$ is produced, (ii) averaging on rows the values of $\mathrm{A}_{\text {norm }}$, the eigenvector $\left(W^{T}\right)$ is finally estimated.

The main advantage of the AHP method is the consistency ratio $(C R)$, which shows to which extent all pairwise subjective assessments of goals or alternatives against goals are consistent. An inconsistency occurs if a certain number of items are ranked in an arbitrary manner; by contrast, consistency means that if an alternative $a$ is two times more important than $b$, and $b$ is three times more important than c, then $a$ shall be narrowly six times more important than $c$ (Coulter et al. 2006). The consistency ratio is computed as follows:

Matrix A, multiplied by $W^{T}$ gives the array $Q$, white the principal eigenvalue $\left(\lambda_{\max }\right)$ is then given by equation (4):

$$
\lambda_{\max }=\frac{1}{n} \sum_{i=1}^{n} \frac{q_{i}}{w_{i}^{T}}
$$

where $n$ is the number of items considered, $w_{i}^{T}$ is the $i^{\text {th }}$ component of the eigenvector $W^{\top}$ and $q_{i}$ is the $\mathrm{i}^{\text {th }}$ value of the array $\mathrm{Q}$.

The consistency index $C I$ is given by equation (5):

$$
C I=\frac{\lambda_{\max }-n}{n-1}
$$

The consistency ratio $(C R)$ is given by dividing $C I$ to $\mathrm{RI}$, where RI is the random inconsistency, taken from Table 3.

The indices given in the second row if Table 3 were averaged after 50000 simulations, each simulation randomly assigning one of those 17 possible values $(1 / 9,1 / 8, \ldots, 7,8,9)$ to each cell of matrix A, with reciprocals bellow the diagonal, in symmetric positions (Saaty 2013).

As already stated, a separate analysis was carried out for benefits, costs and risks, according to $B C R$ methodology, using equal weights ${ }^{2}$ for benefits, costs and risks. Within the benefits and costs we have pondered more the so-

${ }^{2}$ Assigning different weights to aggregated benefits, costs and risks does not change the order of alternatives. cial benefits and costs, as shown in the second column of Table 6 (weights are in brackets). For most criteria the four alternatives were pairwise compared according to AHP methodology (Saaty 1980), excepting quantitative criteria (growth of stumpage value, investment value, and maintenance costs) for which the effective values were normalized using relation (6):

$$
w_{i}=\frac{a_{i}}{\sum_{i} a_{i}}
$$

where $a_{i}$ is the effective value taken by alternative $\mathrm{i}$ for a given criterion.

\section{Criteria setting-up}

The timber volume opened by each new road and the expected value of the investment were taken from the opportunity studies while the expected growth of stumpage residual values was assessed by transition matrices, one for each alternative, as presented in Table 5 .

In these matrices, the volumes that remain in the same category of hauling distance are stored into the cells placed along the main diagonal, while the volumes that move to shorter hauling distances are recorded above the main diagonal, on the corresponding rows. The status quo distribution of volumes on skidding distances is presented on the $6^{\text {th }}$ row of the table and the new distribution on the last but one column. The values in the last column were calculated by multiplying the volumes on hauling distances with the corresponding average prices (the $6^{\text {th }}$ row of the same table).

The expected values of the timber corresponding to the status quo were given by the products between initial distribution of volumes against hauling distances and the average prices stored on the $7^{\text {th }}$ row of the same table.

The fuel consumption for harvesting operations takes the maximum value for the status quo situation and gets smaller and smaller as the road density grows; even though we had no 
Table 3 Random Index (Saaty 2013)

\begin{tabular}{lllllllllllllll}
\hline $\mathrm{N}$ & 2 & 3 & 4 & 5 & 6 & 7 & 8 & 9 & 10 & 11 & 12 & 13 & 14 & 15 \\
\hline $\mathrm{RI}$ & 0 & 0.58 & 0.89 & 1.11 & 1.25 & 1.35 & 1.40 & 1.45 & 1.49 & 1.52 & 1.54 & 1.56 & 1.58 & 1.59 \\
\hline
\end{tabular}

Table 4 Benefits, costs and risks associated to new forest roads

\begin{tabular}{|c|c|c|}
\hline \multirow[b]{2}{*}{ Benefits } & Private & $\begin{array}{l}\text { 1) Higher residual value for stumpage to be harvested (stumpage price) } \\
\text { 2) More access to non-wood products (non-wood products) }\end{array}$ \\
\hline & Social & $\begin{array}{l}\text { 1) Easy access in case of labour accidents (easy access) } \\
\text { 2) Easy access to remote households or private facilities (remote } \\
\text { facilities); } \\
\text { 3) Higher tourism potential (tourism) }\end{array}$ \\
\hline \multirow[b]{2}{*}{ Costs } & Private & $\begin{array}{l}\text { 1) Cost of the new roads (investment) } \\
\text { 2) Fuel consumption during harvesting operations (fuel consumption) } \\
\text { 3) Road maintenance (maintenance cost) }\end{array}$ \\
\hline & $\begin{array}{l}\text { Social and } \\
\text { ecological }\end{array}$ & $\begin{array}{l}\text { 1) Disruption on hydrological network of the area (Water regime); } \\
\text { 2) Degraded natural landscape (Landscape) } \\
\text { 3) Habitats fragmentation (Habitat fragmentation) } \\
\text { 4) Soil displacement (soil displacement) }\end{array}$ \\
\hline Risks & & $\begin{array}{l}\text { 1) Constructors' bankruptcy (Bankruptcy) } \\
\text { 2) Cash default } \\
\text { 3) Landslides in case of massive rainfalls (Landslides) } \\
\text { 4) Bridges broken by floods (Broken bridges) } \\
\text { 5) Illegal logging on the new roads (Illegal activities, including } \\
\text { poaching) }\end{array}$ \\
\hline
\end{tabular}

precise data about fuel consumption, it makes sense to consider the largest possible gap between the two extreme situations (the status quo and the whole new network in place) simply because cable cranes cannot be used without new roads due to the slopes' configuration and long hauling distances.

We have chosen only fuel consumption as a proxy for harvesting cost because its variation can be assessed quite accurately for different harvesting schemes, with and without cable cranes, taken also into consideration the amount of timber transported uphill and downhill respectively. Although shorter hauling distance facilitate higher labour productivity, indicating another worthwhile criterion, for this analysis we have considered just the fuel consumption a proxy for harvesting operations cost in order to have one criterion for investment effort, which is made only once, one criterion for the exploitation costs - which occur from time to time, according to the management plan - and one criterion for the maintenance, which is an overhead.

The same principle holds when it comes to the soil displacement, which has two different technical meanings: on the one hand, it is the amount of soil removed by skidding operations carried out with tractors without any cable crane, soil which is washed downhill, and, on the other hand, we are talking about cutand-fill earthwork required by road construction. The cut-and-fill works ${ }^{3}$ for road construction were not considered as soil displacement in the sense of environmental cost because this criterion refers only to the topsoil scraped by the logs during skidding operations, carried out by tractors only (A0), by cable cranes and tractors (A1 and A2), or by cable cranes only (A3). Keeping on logging without cable cranes which is the status quo is a permanent cause

${ }^{3}$ The fuel consumed for cut-and-fill works pertains to the investment criterion, which is a private cost. 
Table 5 Matrix of transitions from long to shorter hauling distances for the first alternative (RI, RIII, RIV, $\mathrm{RV}$, and RVI)

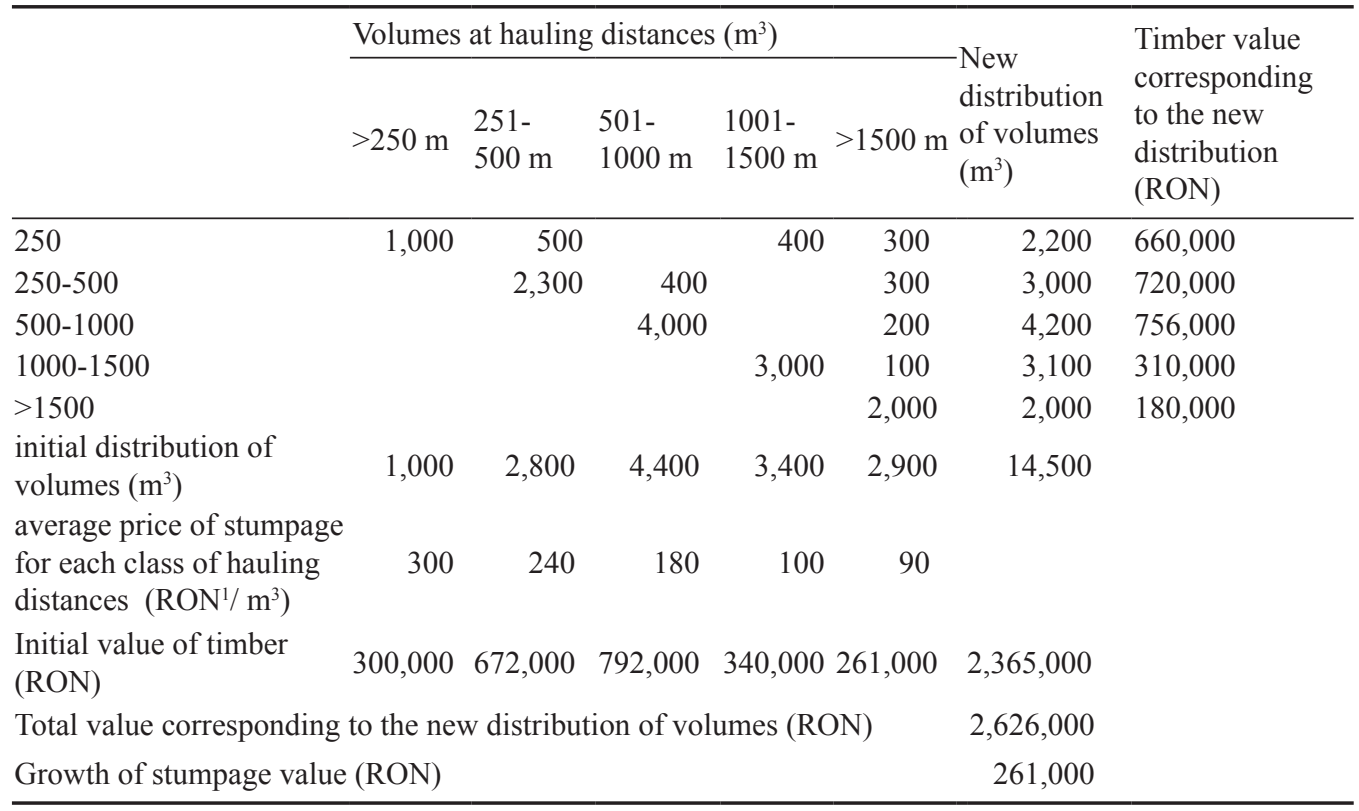

Note. ${ }^{1} \mathrm{RON}-$ Romanian currency; $1 \mathrm{RON}=0.22 €$

Table 6 Results of benefit-cost-risk analysis

\begin{tabular}{|c|c|c|c|c|c|c|c|}
\hline \multicolumn{2}{|c|}{ Criteria (weights) } & sub-criteria & $\begin{array}{l}\text { Subcriteria } \\
\text { weights }\end{array}$ & A0 & & & A3 \\
\hline \multirow{6}{*}{ Benefits } & \multirow{2}{*}{$\begin{array}{l}\text { Private } \\
(0.167)\end{array}$} & Stumpage price growth & 0.833 & 0.120 & 0.207 & 0.272 & 0.401 \\
\hline & & Non-wood products & 0.167 & 0.104 & 0.299 & 0.273 & 0.324 \\
\hline & \multirow{3}{*}{$\begin{array}{l}\text { Social } \\
(0.833)\end{array}$} & Easy access in case of accident & 0.625 & 0.106 & 0.150 & 0.372 & 0.372 \\
\hline & & Access to remote properties & 0.136 & 0.175 & 0.246 & 0.289 & 0.289 \\
\hline & & Tourism & 0.238 & 0.144 & 0.161 & 0.27 & 0.425 \\
\hline & \multicolumn{2}{|c|}{ Benefit quotients } & & 0.123 & 0.175 & 0.325 & 0.375 \\
\hline \multirow{9}{*}{ Costs } & \multirow{3}{*}{$\begin{array}{l}\text { Private } \\
(0.111)\end{array}$} & Investment & 0.705 & 0.000 & 0.396 & 0.526 & 0.734 \\
\hline & & Fuel consumption & 0.211 & 0.613 & 0.222 & 0.093 & 0.071 \\
\hline & & Road maintenance & 0.084 & 0.071 & 0.396 & 0.526 & 0.734 \\
\hline & \multirow{4}{*}{$\begin{array}{l}\text { Social } \\
(0.889)\end{array}$} & Water protection & 0.464 & 0.049 & 0.135 & 0.26 & 0.556 \\
\hline & & Landscape & 0.097 & 0.085 & 0.179 & 0.358 & 0.379 \\
\hline & & Habitat disturbance & 0.184 & 0.144 & 0.178 & 0.278 & 0.400 \\
\hline & & Earth movement & 0.254 & 0.622 & 0.165 & 0.123 & 0.089 \\
\hline & \multicolumn{2}{|c|}{ Cost quotient } & & 0.212 & 0.177 & 0.207 & 0.177 \\
\hline & \multicolumn{2}{|c|}{ Benefits/Costs } & & 0.596 & 0.987 & 1.253 & 0.908 \\
\hline \multirow{7}{*}{ Risks } & & Constructor's bankruptcy & 0.266 & 0.071 & 0.099 & 0.099 & 0.531 \\
\hline & & Cash default & 0.488 & 0.056 & 0.100 & 0.193 & 0.651 \\
\hline & & Landslides & 0.104 & 0.075 & 0.135 & 0.216 & 0.575 \\
\hline & & Broken bridges & 0.094 & 0.125 & 0.098 & 0.195 & 0.582 \\
\hline & & Illegal cuttings & 0.049 & 0.136 & 0.106 & 0.202 & 0.556 \\
\hline & & risk quotient & & 0.072 & 0.104 & 0.171 & 0.601 \\
\hline & & $B C R$ & & 8.019 & 9.525 & 7.320 & 1.512 \\
\hline
\end{tabular}


of soil erosion, and the soil movement, technically speaking, outweighs any other alternative with new forest roads in place.

\section{Results}

The multi-criteria analysis was carried out separately for benefits, costs and risks, the weights of the sub-criteria are the ones presented in the $2^{\text {nd }}$ and the $4^{\text {th }}$ columns of Table 6 . According to MCA terminology, the values recorded on the alternatives' columns render utilities, while the values recorded on criteria columns are weights.

The values in columns A0 to A3 are given either by pairwise comparisons between alternatives against each sub-criterion or by simple normalization for those sub-criteria where effective values were available (total investment, stumpage value, and road maintenance costs). Where pairwise comparisons have been made, the consistency ratio was kept below the recommended threshold of 0.1 .

The two types of quotients, one for benefits and one for costs, were given by summing up the products between the corresponding utilities below each alternative and the weights of the corresponding sub-criteria; further, the resulting value was multiplied with the criteria weight, either private or social.

The risks were estimated in the same way, but having no hierarchy of criteria and sub-criteria the risk quotient is a simple sum of products between weights and utilities (columns A0 to A3).

The first analysis was carried out considering that social benefits and costs are more important than private costs and benefits. The $B C R$ index takes the greatest value for the first alternative (A1), followed by the status quo situation (A0) and then by the second alternative (A2); A3 (i.e. the whole transportation network) follows far behind. However relying only on the $B C R$ index can be problematic, since this index is based on $B / C$ ratio, divided to the risk quotient. When risk coefficient is very small, which is the case for the status quo situation, $B C R$ index gets the highest value, meaning that doing nothing is always better.

Therefore an additional hint for the appropriate decision may be the benefit-cost ratio $(B / C)$, presented in the same table, above the risks. Bearing in mind that $B / C$ should be greater than one, the appropriate solution is A2; however, A1 in not so bad, because the $B / C$ is close to one $(0,987)$, while $A 0$ and $A 3$, with lower $B / C$ indices, could be ruled out.

A thorough analysis shows that only two small roads make the difference between A1 and A2: RII, which opens compartments 53, $54,55 \mathrm{~A}$ and $55 \mathrm{~B}$, where regular harvesting operations are allowed, and RIV.1, which opens compartments 45, 46 and a small part of compartment 47, where regular fellings are banned anyway (dotted background on the map in fig. 1 renders green tree retention). The trade-off is to add one of these roads to alternative A1 (or to take it away from A2) but the question is which one: RII (1.19 km length), or R IV.1 (3.13 km length)? The answer is straightforward: RII, which is shorter, given that expected yields are quite similar (most of all stands opened by this road are scheduled to be thinned at least once in the next two decades).

The second analysis was carried out considering equal weights for private and social benefits and costs and the final results are presented in the last two rows of Table 7 . Now all alternatives have $B / C$ indices smaller than one, but A2 still has the highest value $(0,904)$. When it comes to $B C R$ indices, ruling out $\mathrm{A} 0$ for the reason aforementioned, the best alternative is now A1 $(7,284)$ pointing at the same trade-off between A1 and A 2 already discussed in the previous paragraph.

\section{Discussion}

Most of the benefits, costs and risks taken into account in this problem are hard to cap- 
ture in monetary or quantitative terms. Hence subjective evaluations are inevitable and the AHP procedure fits perfect for such situations. However, the gap between the highest and lowest priority depends on how the decision maker uses the scale of relative importance: the one recommended by the author $(3,5,7$, and 9$)$ or the tightest one, like 2, 3, 4, and 5; (four steps in both situations, without 1 , which means equally important). Making pairwise comparisons with only three items, and keeping $C I$ as low as possible, the difference between the highest and the lowest priority is $0.528(C I=0.03)$ in the first case and $0.396(C I=0.01)$, in the latter case. This simple exercise demonstrates that, in spite of its solid mathematic foundation, AHP outcome depends to a great extent on the manner in which the decision maker wants to differentiate the most important item from the least important one.

This is not quite bad, but most of the critical comments concerning AHP refer to the rank reversal phenomenon which occurs when the decision maker comes up with a new criterion or a new, even irrelevant, alternative; even though that criterion fetches equal scores across alternatives, or the new alternative is just a dummy of one of the initial alternatives, the new rank might be different. This quite narrow topic seems to be prolific since as many as 61 papers have dealt with issue since early 1980 s (Maleki \& Zahir 2013).

Wang et Elhag (2006) found that rank reversal occurs when local priorities are altered by adding or removing an alternative and the solution is to keep the local priorities unchanged. Tam et al (2006) considered that rank reversal is inevitable for methods based on pairwise comparisons since the evaluation process is resumed whenever a new node (alternative or criterion) is added to the hierarchical structure. As a matter of fact rank reversal is associated with many multicriteria methods (García-Cascales et Lamata 2012) even with Data Envelopment Analysis (Wang et Luo 2009).

This shortcoming was somehow avoided in our case study because the problem was split into three separate sub-problems, for benefits, costs and risks. In so doing we have conceived three hierarchies, not one, each of them having up to three levels, which complies with the threshold suggested by Pérez et al (2006), who considered that in more complex hierarchies, with more than three levels, rank reversal may occur.

In our case study a quite strange situation has occurred when private benefits and costs were considered equally important as social benefits and costs (Table 7): the $B / C$ ratios were smaller than the initial $B / R$ ratios when social effects (benefits and costs) had been emphasised. The explanation shall be sought in the relative growth of the stumpage price and investment growth: excepting the status quo (A0), for all alternatives (from A1 to A3) the relative growth of investment are higher than the relative growth of stumpage value, and, multiplied with greater weights ( 0.5 instead of 0.167 and 0.111 respectively), the costs outweighed the benefits and all $B / C$ ratios were smaller than one.

The outcome of this case study is not exactly the most expected one - more roads make the forest owner and the local community better off - because the benefit coefficients do not grow at the same pace as the costs and the risks (see Table 6). This also holds true for tourism value and total investment, both being counterbalanced by a higher risk of cash default and constructor's bankruptcy. Had we dealt with more valuable stands, supposed to fetch higher prices once they were more accessible, and had we considered smaller exposure to cash default, the situation would have been different because the risk associated to the longest network would have probably been smaller, in relative terms.

For the investment problem we have dealt with the outcome also depends to a great extent on how different options are combined into few decision alternatives. In this example we initially have two main networks: a basic 
Table 7 Sensitivity analysis with equal weights for private and social benefits and costs

\begin{tabular}{llllll}
\hline Scenario & Indices & $\begin{array}{l}\mathrm{A} 0 \\
\text { rank(utility) }\end{array}$ & $\begin{array}{l}\mathrm{A} 1 \\
\text { rank(utility) }\end{array}$ & $\begin{array}{l}\mathrm{A} 2 \\
\text { rank(utility) }\end{array}$ & $\begin{array}{l}\mathrm{A} \text { 3 } \\
\text { rank(utility) }\end{array}$ \\
\hline $\begin{array}{l}\text { Emphasis on social } \\
\text { benefits and costs }\end{array}$ & $B / C$ & $4(0.596)$ & $2(0.987)$ & $1(1.253)$ & $3(0.908)$ \\
\cline { 2 - 6 } $\begin{array}{l}\text { Equal weights on } \\
\text { private and social } \\
\text { benefits and costs }\end{array}$ & $B C R$ & $2(8.019)$ & $1(9.525)$ & $3(7.320)$ & $4(1.512)$ \\
\hline
\end{tabular}

one, made of new roads crossing the slopes, and an extended one, with one additional connector across some large compartments (from 34 to 43), which closes the loop with road $\mathrm{R}$ IV and a short road across compartments 2933, (RVII) which, from the economic point of view is a loose end because it hits compartment 29, where regular harvesting operations are banned due to the steep terrain, where only green tree retention is allowed (dotted background on the map, see Figure 1).

\section{Conclusions}

Splitting the benefits and costs into private and social/environmental benefits and costs eases the pairwise assessments between alternatives and gives the opportunity to assign different weights to social outcomes, even though, as demonstrated, the final rank of alternatives does not change. The range of criteria was broadened in order to take into consideration other risks, like a contractor exposed to bankruptcy, or to finance big projects from EU funds or loans, in which case the entrepreneur's default could turn into a serious threat for the whole investment.

The AHP allows different combinations of benefits, costs and risks and, as demonstrated in this study, the relative weights of criteria can be assessed in a very consistent way, compared with any other decision making method, and this is the main advantage of using AHP in complex decisional situations. Such situations typify projects developed in Natura 2000 sites where the environmental impact study shall be backed up by a Strategic Environmental Assessment (Anonymous 2009) which requires thorough analyses on a couple of reasonable alternatives, weighing more the ecological outcomes or risks brought about by any new investment.

\section{Alnowledgements}

The study was supported by RemoteForest research project (PN-II-PT-PCCA-2011-3.21710), financed by the Romanian Scientific Research Authority under the contract No. $118 / 2012$.

\section{References}

Ali J. et al., 2005. The road to deforestation: An assessment of forest loss and its causes in Basho Valley, Northern Pakistan. Global Environmental Change 15(4): 370380. DOI: 10. 1016/j.gloenvcha.2005.06.004.

Ananda J., Herath G., 2003a. Incorporating stakeholder values into regional forest planning: a value function approach. Ecological Economics 45: 75-90. DOI: 10.1016/S0921-8009(03)00004-1.

Ananda J., Herath G., 2003b. The use of Analytic Hierarchy Process to incorporate stakeholder preferences into regional forest planning. Forest Policy and Economics 5: 13-26. DOI: 10.1016/S1389-9341(02)00043-6.

Ananda J., Herath G., 2008. Multi-attribute preference modelling and regional land-use planning. Ecological Economics 65: 325-335. DOI: 10.1016/ j.ecolecon.2007.06.024.

Ananda J., Herath G., 2009. A critical review of multi-criteria decision making methods with special reference to forest management and planning. Ecological Economics 68, 2535-2548. DOI: 10.1016/j.ecolecon.2009.05.010. 
Anonymous 2003. Ministerial Orders 860863 on the methodological guidelines applicable for the framework procedures on environment impact assessment. Official Journal of Romania, vol. 52/30.01.2003.

Anonymous 2007. Forestry and Forest Industry in Romania: wood sector study. Austroprojekt, Agency for Technical Cooperation Ltd., Vienna, 166 p.

Anonymous 2008. Romanian Forest Act. Official Journal of Romania vol. 238 March 27, $1^{\text {st }}$ section.

Anonymous 2009. Study concerning the report on the application and effectiveness of the SEA Directive (2001/42/EC) European Commission, DG ENV, Final report, April 2009, 153 p.

Arnáez J. et al., 2004. Surface runoff and soil erosion on unpaved forest roads from rainfall simulation tests in northeaster Spain. Catena 57(1): 1-14. DOI: 10.1016/ j.catena. 2003.09.002.

Colchero F. et al., 2011. Jaguars on the move: modelling movement to mitigate fragmentation from road expansion in the Mayan Forest. Animal Conservation 14(2): 158-166. DOI: 10.1111/j.1469-1795.2010.00406.x.

Correa C.M.C. et al., 2007. Real and estimative erosion through RUSLE from forest roads in two relief conditions and four soils profile. Scientia Forestalis 35(76): 57-66.

Coulter E.D., Coakley J., Sessions J., 2006. The Analytic Hierarchy Process: A Tutorial for use in prioritizing forest road investments to minimize environmental effects. International Journal of Forest Engineering 17: 51-69.

Demir M., 2007. Impacts, management and functional planning criterion of forest road network system in Turkey. Transportation Research Part A: Policy and Practice 41: 56-68. DOI: 10.1016/j.tra.2006.05.006.

García-Cascales M.S., Lamata M.T., 2012. On rank reversal and TOPSIS method. Mathematical and Computer Modelling 56(5-6): 123-132. DOI: 10.1016/ j.mcm.2011.12.022.

Gumus S., 2009. Constitution of the forest road evaluation form for Turkish forestry. African Journal of Biotechnology 8: 5389-5394.

Hayati E., Abdi E., Majnounian B., Makhdom M., 2013. Application of sensitivity analysis in forest road networks planning and assessment. Journal of Agricultural Science and Technology 15(4): 781-792.

Kangas J., Kuusipalo J., 1993. Integrating biodiversity into forest management planning and decision-making. Forest Ecology and Management 61: 1-15. DOI: 10.1016/0378-1127(93) 90186-Q.

Kurttila M., Pesonen M., Kangas J., Kajanus M., 2000. Utilizing the analytic hierarchy process (AHP) in SWOT analysis - a hybrid method and its application to a forest-certification case. Forest Policy and Economics 1: 41-52. DOI: 10.1016/S1389-9341(99)00004-0.

Lugo A.E., Gucinski H., 2000. Function, effects, and management of forest roads. Forest Ecology and Management 133: 249-262. DOI: 10.1016/S03781127(99)00237-6.

Maleki H., Zahir S., 2013. A comprehensive literature re- view of the rank reversal phenomenon in the Analytic Hierarchy Process. Journal of Multi-Criteria Decision Analysis 20(3-4): 141-155. DOI: 10.1002/mcda.1479.

Martinez-Alier J., Munda G., O’Neill J., 1998. Weak comparability of values as a foundation for ecological economics. Ecological Economics 26: 277-286. DOI: 10.1016/S0921-8009(97)00120-1.

Mendoza G.A., Martins H., 2006. Multi-criteria decision analysis in natural resource management: A critical review of methods and new modelling paradigms. Forest Ecology and Management 230: 1-22. DOI: 10.1016/ j.foreco.2006.03.023.

Miller G.A., 1957. The magical number of seven plus or minus two: Some limits of our capacity for processing information. Psychological Review 63: 81-97. DOI: 10.1037/h0043158.

Pérez J., Jimeno J., Ethel Mokotoff, 2006. Another potential strong shortcoming of AHP. 14(1): 99-111. DOI: 10.1007/BF02579004.

Rafatnia N.A., Abdi O., Shataei J.S., 2006. Determining proper method of preliminary forecasting of mountain and forest roads using GIS. Iranian Journal of Forest and Poplar Research 14: 244-257.

Rametsteiner E., Simula M., 2003. Forest certification - an instrument to promote sustainable forest management? Journal of Environmental Management 67(1): 87-98. DOI: 10.1016/ S0301-4797(02)00191-3.

Saaty T.L., 2013. Principia Matematica Decernendi [Mathematical principles of decision making]. The Complete Theory of Analytic Hierarchy Process. RWS Publications, Pittsburgh, pp. 154-155.

Saaty T.L., 1980. The analytic hierarchy process planning, priority setting, resource allocation. McGraw-Hill, New York.

Saaty T.L., 1994. Highlights and critical points in the theory and application of the Analytic Hierarchy Process. European Journal of Operational Research 74: 426-447. DOI: 10.1016/ 0377-2217(94)90222-4.

Saphores J.-D.M., Vincent R., Marochko J., Abrudan V. I.V., Bouriaud L., Zinnes C., 2006. Detecting collusion in timber auctions: An application to Romania. World Bank Policy Research Working Paper No. 4105, p. 58.

Šegotić K., Posavec S., 2007. Assessing forest value with the eigenvector method. Ekológia 26: 362-370.

Shiba M., 1995. Analytic Hierarchy Process (AHP)-Based multi-attribute benefit structure analysis of road network systems in mountainous rural areas of Japan. International Journal of Forest Engineering 7(1): 41-50. DOI: $10.1080 / 08435243.1995 .10702677$.

Tam C.M, Tong Thomas K.L, Chiu Gerald, W.C., 2006. Comparing non-structural fuzzy decision support system and analytical hierarchy process in decision-making for construction problem. European Journal of operational Research 174: 1317-1324. DOI: 10.1016/ j.ejor.2005.03.013.

Tadajewski M., 2009. The debate that won't die? Values incommensurability, antagonism and theory choice, pp. 467-485. 
Vacik H., Lexer M.J., 2001. Application of a spatial decision support system in managing the protection forests of Vienna for sustained yield of water resources. Forest Ecology and Management 143: 65-76. DOI: 10.1016/ S0378-1127(00)00506-5.

Wang Y.-M., Elhag T.M.S., 2006. An approach to avoiding rank reversal in AHP. Decision Support Systems 42(3): 1474-1480. DOI: 10.1016/j.dss.2005.12.002.

Wang Y.-M., Luo Y., 2009. On rank reversal in decision analysis. Mathematical and Computer Modelling 49(5-
6): 1221-1229. DOI: 10.1016/j.mcm.2008.06.019.

Winston W.L., 1994. Operations research: Applications and algorithms. Duxbury Press International Thomson Publishing, $3^{\text {rd }}$ Edition, $1318 \mathrm{p}$.

Wolfslehner B., Vacik H., Lexer M.J., 2005. Application of the analytic network process in multi-criteria analysis of sustainable forest management. Forest Ecology and Management 207: 157-170. DOI: 10.1016/ j.foreco.2004.10.025. 